\title{
Production, post-harvest management and gender dynamics among smallholder peanut farmers in Haiti
}

\author{
Genti Kostandini ${ }^{1 *}$, James Rhoads ${ }^{2}$, Gregory E. MacDonald ${ }^{3}$, Eftila Tanellari ${ }^{4}$, Rob Johnson ${ }^{5}$, Eric Carroll ${ }^{5}$ and \\ Gael Pressoir ${ }^{6}$
}

\begin{abstract}
Background: Peanut is an important crop for farmers in Haiti. Currently, very limited information is available on farmers'yields, production practices as well as post-harvest practices that reduce aflatoxin prevalence and increase food security.

Methods: A household survey from Haiti and regression analysis are used to examine peanut production among small female and male-headed households in terms of yield and post-harvest practices (use of tarps for drying and sorting) which are very important for preventing aflatoxins.

Results: We find that yields are low (average $270 \mathrm{~kg} / \mathrm{ha}$ ) compared to more developed countries (more than $2000 \mathrm{~kg} / \mathrm{ha}$ ) and there is substantial room for improvement. Female-headed households have lower yields compared to male-headed households and farming on a slope imposes a penalty on peanut yields. We did not find significant differences between male and female-headed households on post-harvest practices when it comes to the use of a tarp for drying peanuts, but households where decisions were made jointly are more likely to use a tarp.

Conclusions: There is substantial room for improving peanut yields among smallholder farmers in Haiti. Households with more access to capital, as measured by off-farm income and receiving remittances, are associated with an increase the likelihood of tarp use, which may reduce levels of aflatoxin contamination. In addition, saving more seed and joint decisions are associated with an increased level of sorting efforts, which will lower aflatoxin prevalence and increase food security.
\end{abstract}

Keywords: Peanut productivity, Drying and sorting practices, Safety, Haiti

\section{Introduction}

With the world's population projected to grow to 9 billion in the next few decades, food security remains one of the most important challenges [5]. With most of the population growth expected to come from developing countries, food production must grow by $70 \%$ and producing more food will largely depend on increasing crop yields not

\footnotetext{
*Correspondence: gentik@uga.edu

1 Department of Agricultural and Applied Economics, University of Georgia, 206 Stuckey Building, Griffin, GA 30223, USA

Full list of author information is available at the end of the article
}

farming more land [12]. Gender equity access to productive assets [11] and the use of post-harvest technologies [35] have been identified as important means to increase productivity and increase food security. This article focuses on Haiti which is one of the poorest countries in the Western Hemisphere and imports more than half of the food it consumes. As of 2018, it ranked 168 out of 189 in the Human Development Index [41]. Haiti has chronic issues of food security, and the average caloric intake is $73 \%$ of the World Health Organization's recommended minimum [24]. Haitians rely heavily on remittances from

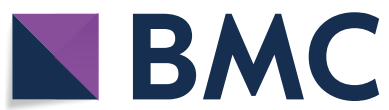

(c) The Author(s) 2021. This article is licensed under a Creative Commons Attribution 4.0 International License, which permits use, sharing, adaptation, distribution and reproduction in any medium or format, as long as you give appropriate credit to the original author(s) and the source, provide a link to the Creative Commons licence, and indicate if changes were made. The images or other third party material in this article are included in the article's Creative Commons licence, unless indicated otherwise in a credit line to the material. If material is not included in the article's Creative Commons licence and your intended use is not permitted by statutory regulation or exceeds the permitted use, you will need to obtain permission directly from the copyright holder. To view a copy of this licence, visit http://creativeco mmons.org/licenses/by/4.0/. The Creative Commons Public Domain Dedication waiver (http://creativecommons.org/publicdomain/ zero/1.0/) applies to the data made available in this article, unless otherwise stated in a credit line to the data. 
abroad, representing about one-fifth of the gross domestic product in recent years [4]. More than $50 \%$ of the households live in rural areas, and their primary source of income comes from farming activities. Formal employment is minimal (13 percent); thus, agriculture and urban informal sectors provide most of the employment opportunities [4]. Most Haitian households are still very poor even though extreme poverty decreased in Haiti from 31 percent in 2000 to 24 percent in 2012 [40]. Gender inequality is prevalent in Haiti, where women are often considered second-class citizens [27]. For example, it has been reported that families will often preferentially invest in the education of male children at the expense of female children [27].

Peanuts are a vital consumption and cash crop for smallholder farmers in Haiti, especially where the average subsistence farm is about 1.8 ha, and many farms are located on steep slopes of more than $20^{\circ}$ [23]. Peanut yields in Haiti are quite low, but can be increased by as much as tenfold as they are found in controlled trials in Haiti. The average yield in the sample is $270 \mathrm{~kg} / \mathrm{ha}$, while Fulmer et al. [15] conducted controlled input and variety trials in Haiti found yields of over $3000 \mathrm{~kg} / \mathrm{ha}$. Even in low-input field conditions, yields should be able to double or triple from the $270 \mathrm{~kg} / \mathrm{ha}$ yield estimate. During the last decade, there have been multiple efforts to increase peanut productivity in Haiti, some funded by the United States Agency for International Development (USAID) [37]. Haiti was part of the USAID's Feed the Future program to increase food security, poverty, and malnutrition in developing countries [29]. As a result, scientists from US universities collaborated with Haitian scientists to evaluate new varieties and improved production practices to increase yields and improve quality.

In addition to low yields, another critical challenge for peanut productivity in Haiti is the prevalence of aflatoxins. Aflatoxins are toxic metabolites produced by Aspergillus fungi [38] and linked to a range of severe health issues in humans and livestock throughout the world [33]. Aflatoxin exposure is a significant risk factor for hepatocellular carcinoma, especially when hepatitis B infection is present. Recent evidence suggests that aflatoxin may be an underlying determinant of stunted child growth and may lower cell-mediated immunity [17]. Filbert and Brown [13] found aflatoxin prevalence in Haitian peanut butter in 16 out of 18 samples that were contaminated above the United States Department of Agriculture (USDA) threshold level ( $>20$ parts per billion ppb), and 11 were above $200 \mathrm{ppb}$, with a maximum of $700 \mathrm{ppb}$. They also found that hand sorting to remove broken and visibly damaged kernels is effective and reduces aflatoxin concentration by 97 percent. They further recommended sorting before storage and again before using it into food products. Similarly, Schwartzbord and Brown [32] found high levels of aflatoxin $(>20 \mathrm{ppb})$ in 14 percent of the raw peanut samples $(n=21)$ and 94 percent of peanut butter samples $(n=32)$ from samples collected in Port-au-Prince and Cap Haitian. In addition to sorting, as explained in more detail later, using tarps for drying peanuts, as opposed to spreading on bare soil, which is a common strategy used in developing countries, is also an effective way to reduce aflatoxin levels. Magnan et al. [19] conducted randomized control trials with peanut farmers in Ghana and found that tarp distribution can reduce aflatoxin levels by up to 30 percent.

Despite the economic, nutritional, and cultural importance of peanuts in Haiti [23], and the prevalence of aflatoxin, very little has been documented about the role of gender, production practices, yield, and post-harvest management for peanut at the household level. To our knowledge, this study is one of the first attempts to explore those factors that affect peanut production and post-harvest management in Haiti. The objective of this paper is threefold. First, we have evaluated the socioeconomic and selected environmental factors that affect peanut productivity in Haiti relative to yield. Second, we have examined gender differences in productivity between male and female-headed households, as evidence suggests productivity and input allocation differences among male versus female-headed households (e.g., $[28,36]$ ) Third, we have evaluated factors that affect post-harvest management practices that reduce loss and improve food safety specifically by reducing aflatoxin contamination, including evaluation of differences between male and female-headed households. Ultimately these findings will contribute to a better understanding of factors affecting production and current practices for aflatoxin prevention. By documenting these findings, we hope to indicate potential avenues for improvement in both quantity and quality of peanut as it constitutes an essential part of the cropping portfolio for thousands of farmers in Haiti and other developing countries.

To answer these questions, we analyzed data from a survey of peanut producing households collected in the Central Plateau region and the Northeast region in 2014. The questionnaire inquired about peanut varieties, production practices, prices, inputs, household wealth indicators, livestock holdings, and agricultural and nonagricultural economic activities. The questionnaire also included questions about post-harvest practices, which are important for aflatoxin control.

The rest of the paper is organized as follows: "Peanut production in Haiti and related literature" section provides further background information on peanut production in Haiti and related literature documented in preparation of the survey instrument, while "Materials 


\title{
Peanuts (Arachis hypogaea) Agricultural land planted to peanut by communal section
}

\author{
$\%$ of land growing peanut

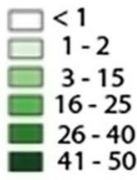

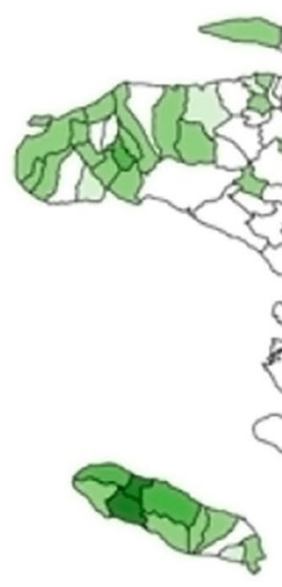
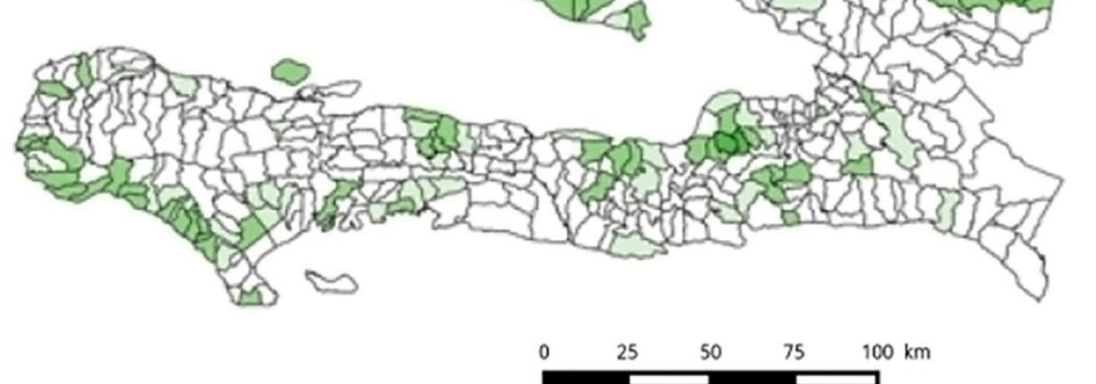

Fig. 1 Distribution of peanut production in Haiti. Area planted in peanuts per communal section (1 Carreaux=12,900 m²). Source: [14]

and methods" section describes materials and methods. Results are discussed in "Results" section, and discussion and conclusions are provided in "Discussion and conclusions" section.

\section{Peanut production in Haiti and related literature}

Due to the limited number of peer-reviewed publications related to peanut production in Haiti, preliminary formative research in the form of key informant interviews and review of grey literature (e.g., [32]) were conducted in order to provide context and prepare the survey instrument.

Despite the limited acreage of peanut produced in Haiti, peanuts provide significant economic value to smallholder farmers in the areas of the country where planted. The 2009 agricultural census conducted by the Ministry of Agriculture, Natural Resources and Rural Development (MARNDR) estimated that 70,112 farms produced peanut or 7.2 percent of the total. By comparison, 75.2 percent produce maize, and 48.7 percent produce pigeon pea (unpublished). Peanut is grown throughout the country, but, as shown in Fig. 1, the primary production regions are the Northeast and the Central Plateau, along the border with the Dominican Republic [14] and these two regions account for about 70 percent of the peanut production in Haiti. Due to its relatively limited requirements for soil fertility as a legume and drought tolerance, peanut production is quite common in these regions where rainfall is limited, and soils are often sandy or heavily eroded. Like most agriculture in Haiti, peanut production is dominated by smallholder farmers with $1 / 4$ to 1 ha lots on average. Between 2010 and 14, the FAO estimates yields to be between 850 and $950 \mathrm{~kg} / \mathrm{ha}$ [16]. However, empirically measured yields reported of peanuts are about $300 \mathrm{~kg}$ per ha, due to low soil fertility, periodic drought, and poor quality seed [21], and our data are more in line with these findings.

There are two distinct production regions differentiated by rainfall patterns, cropping cycle, and the dominant peanut variety, as confirmed by our data. The Northeast region is marked by a less distinct seasonal rainfall pattern, allowing for less constrained planting dates and two longer planting seasons, roughly March to July and August to December, with the first season usually having a higher planted area. Most farmers in this region prefer a small-seeded local landrace Runner-type variety peanut that requires roughly 130 days to mature. This variety has a branching habit, slightly higher yield potential, and is regionally preferred for peanut butter, due to its higher oil content. The Central Plateau is marked by shorter duration, more defined rainy season in the spring and summer months, and is dominated by a small-seeded, landrace Valencia-type variety with a distinct red seed coat and a shorter cropping duration of roughly $80-90$ days. The 
short duration and lack of seed dormancy allow for two successive crops in the spring and summer, with the first planting generally more extensive. This variety also has a more upright, bunch-type growth habit, which allows for smoother manual harvesting.

Traditional production practices consist of several basic stages (land preparation, seeding, weeding, digging, threshing, drying, sorting, and marketing). Both men and women participate in the production, but informants all noted that certain stages are generally more associated with a specific gender. Field preparation and digging at harvest, which are more physically demanding are mainly done by men. Both men and women participate in seeding and weeding, but more responsibility in post-harvest activities, including threshing/plucking, drying, sorting, and marketing is taken over by women. Almost all activities are done manually, though some land preparation, as our data below indicate, is accomplished through tractor or animal traction. Our data also confirm that currently few inputs (i.e., pesticides, fertilizer) are used beyond land, seed, and labor, but the costs of each of these inputs are limiting to timely planting, establishing adequate plant populations, and improving potential yields.

Peanuts are an important crop in many developing countries, and despite the paucity of literature for Haiti, there have been numerous studies for other countries related to our particular topics of interest. For example, Tanellari et al. [34] found in Uganda that female-headed households are less likely to adopt improved peanut varieties compared to male-headed households, demonstrating gender differences in technology adoption. Similarly, Launio et al. [23] examined factors associated with increased adoption of agricultural technology for peanut farming and found training, gender, membership in organizations, and family size to be the most important factors affecting these decisions. Ibrahim et al. [20] used household data from Northern Ghana and found that organizational membership, location, and owning a bicycle were associated with an increased probability of adoption. Generally, studies in developing countries find that adopting improved peanut varieties and agricultural technology (including fertilizer, improved agronomic practices, etc.) improves household income and lowers poverty (e.g., $[18,22,31])$.

\section{Materials and methods \\ Data}

The data used in this paper were collected through a survey conducted in the Northeast and the Central Plateau in 2014 in collaboration with Acceso Haiti. ${ }^{1}$ These sites were chosen because traditionally, they are important for peanut production in Haiti and are also subject to ongoing efforts aimed at improving peanut productivity with several international and local organizations, including Acceso Haiti, a for-profit social agribusiness working with over 2000 peanut farmers in the two regions.

The farmers were located across different villages where Acceso had a presence at the time. They were present in 3 villages in the Northeast close to the Dominican border and in 16 villages in Central Plateau. They provided a list of all farmers engaged in peanut farming in each village and based on the population of each village we randomly chose 160 households from the Northeast and 390 households from the Central Plateau. The survey was administered in Haitian Creole (the local language) by trained local enumerators. A pre-survey test was conducted prior to the main data collection effort. Two local enumerators along with a supervisor conducted the survey in the Northeast region, and four enumerators, along with a supervisor, conducted the survey in the Central Plateau. The survey resulted in a total of 507 farmers consisting of 152 farmers in the Northeast and 355 farmers in the Central Plateau. The survey was conducted in 2014 from the beginning of September until mid-October and covered peanut production in the spring season in both regions. The farmers were asked a series of questions on the household composition, income, peanut production practices, livestock, on and off-farm work, etc. Table 1 provides a description of the variables of interest in peanut production, household demographics, and livestock holdings, and their summary statistics.

Gathering accurate yield data is challenging, especially when relying on farmer recall and widely variable local measures of both area planted and harvested mass [6]. Peanut in Haiti is most often measured and sold volumetrically using reused \#10 cans called marmit(s), which can lead to highly variable weights based on seed size [25]. Farmers reported yield in local metrics, which were converted standard metrics $(\mathrm{kg})$. The yield was not reported from all farmers interviewed, and from those that reported yields, we see a substantial dispersion of yields with a mean yield of $271 \mathrm{~kg} / \mathrm{ha}$ and a standard deviation of $483 \mathrm{~kg} / \mathrm{ha}$. Twenty-one percent of the households interviewed were female-headed households, and the rest were male-headed households. An additional question was asked about decision-making related to farming/working the land (for example, whether or not to buy inputs, pay labor, harvest timing and labor, and selling of

\footnotetext{
1 The survey was approved by the University of Georgia Institutional Review Board (IRB ID \# STUDY00000870).
} 
Table.1 Peanut production, household demographics and livestock in the central Plateau and North Eastern Haiti in 2014

\begin{tabular}{|c|c|c|c|}
\hline Variable & $\mathbf{N}$ & Mean & Std. Dev \\
\hline Yield (kg/ha) & 385 & 271 & 483 \\
\hline Land in peanuts (ha) & 396 & 0.96 & 0.61 \\
\hline Male respondent & 507 & 0.76 & 0.43 \\
\hline Weekly income (Gourdes) & 316 & 1,976 & 2,625 \\
\hline Annual income (Gourdes) & 318 & 47,302 & 51,354 \\
\hline Annual peanut consumption $(\mathrm{kg})$ & 465 & 9.07 & 8.35 \\
\hline Remittances from abroad & 491 & 0.18 & 0.39 \\
\hline Female-headed household & 507 & 0.21 & 0.41 \\
\hline Aflatoxin knowledge & 507 & 0.31 & 0.46 \\
\hline Difficulty of selling peanuts & 502 & 0.24 & 0.43 \\
\hline Wife makes decisions & 507 & 0.10 & 0.30 \\
\hline Joint decisions & 507 & 0.59 & 0.49 \\
\hline Northeast & 507 & 0.30 & 0.46 \\
\hline Number of adults & 504 & 1.98 & 0.45 \\
\hline No schooling & 507 & 0.23 & 0.42 \\
\hline Primary education & 507 & 0.48 & 0.50 \\
\hline Secondary education & 507 & 0.23 & 0.42 \\
\hline Other education & 507 & 0.02 & 0.15 \\
\hline College education & 507 & 0.03 & 0.16 \\
\hline Number of children & 499 & 3.61 & 2.04 \\
\hline Farming experience (years) & 469 & 17.69 & 9.24 \\
\hline Works with an organization & 502 & 0.34 & 0.48 \\
\hline Cattle (yes or no) & 507 & 0.68 & 0.47 \\
\hline Goats (yes or no) & 507 & 0.76 & 0.43 \\
\hline Pig (yes or no) & 507 & 0.50 & 0.50 \\
\hline Horse (yes or no) & 507 & 0.40 & 0.49 \\
\hline
\end{tabular}

Conversion rate was U.S. \$1 to 51 Haitian Gourdes in 2015

the harvested peanuts) and 59 percent responded that they make decisions jointly, 10 percent responded that the wife makes the decisions and 31 percent responded that the husband makes the decisions. ${ }^{2}$ The educational level of the households was low, with 23 percent reporting no schooling and 48 percent reporting only primary education. Questions about livestock suggest that goats are ubiquitous (76 percent of households had goats) in these regions, and 68 percent of them also raise cattle.

Additional information on the peanut varieties, peanut production, drying, and storage practices are reported in Table 2. From the data, it is apparent that farmers in the Northeast exclusively use the local Runner variety while farmers in the Central Plateau use the local Valencia

\footnotetext{
${ }^{2}$ We need to make the reader aware that the answer to this question may be subjective based on the person we interviewed in the household. We did not interview all the household members that make decisions to ensure that we had a consensus on the answer to this question.
}

Table 2 Peanut cultivars, drying and storing practices in the central Plateau and North Eastern Haiti in 2014

\begin{tabular}{llll}
\hline Variable & N & Mean & Std. Dev \\
\hline Runner variety & 507 & 0.29 & 0.46 \\
Valencia variety & 507 & 0.70 & 0.46 \\
Saved seed from previous season & 507 & 0.56 & 0.50 \\
Half land or more on a slope & 507 & 0.43 & 0.49 \\
Uses fertilizer & 507 & 0.11 & 0.32 \\
Weeding & 507 & 0.97 & 0.18 \\
Dries peanuts on tarp & 507 & 0.51 & 0.50 \\
Dries peanuts on soil & 507 & 0.43 & 0.50 \\
Dries peanuts on other surface & 507 & 0.04 & 0.20 \\
Dries for 2-3 days & 507 & 0.04 & 0.19 \\
Dries for 4 days & 507 & 0.34 & 0.47 \\
Dries for 5 days & 507 & 0.35 & 0.48 \\
Dries for 6 days or more & 507 & 0.28 & 0.45 \\
Sorts peanuts & 507 & 0.95 & 0.21 \\
Sorts all bad peanuts & 481 & 0.27 & 0.44 \\
Stores at home & 507 & 0.79 & 0.41 \\
Stores at a depot & 507 & 0.21 & 0.41 \\
Uses bad peanuts as fuel & 507 & 0.07 & 0.25 \\
\hline
\end{tabular}

variety. More than half the farmers (56 percent) saved seed from the previous year, indicating that farmers do rely mostly on recycling seed; however, a significant portion buys seed from the market annually. About 43 percent of the production takes place on land where half or more of the area is sloping land, suggesting that mechanization could be challenging on a significant part of the planted area. Almost all farmers (97 percent) report weeding as a standard practice, but only 11 percent reported using fertilizer.

As mentioned above, aflatoxins are a severe problem in peanuts, and their prevalence is highly dependent on post-harvest practices, including drying and storage [33]. Knowledge of aflatoxins is present in only 31 percent of the respondents and 24 percent of the households had difficulties selling their peanuts. ${ }^{3,4}$ Statistics on drying practices suggest that 43 percent of the farmers dry their peanuts on bare soil, which increases the likelihood of aflatoxin contamination since Aspergillus flavus is a soil fungus and continued soil contact increases drying time (Hofmann et al. 2017). Fifty-one percent of the farmers dry peanuts on a tarp, which is considered an improved

\footnotetext{
${ }^{3}$ Selling difficulties are not necessarily related to aflatoxin since no one tests for aflatoxins except MFK and Acceso Haiti.

4 The exact question on the questionnaire on aflatoxin knowledge was, "Are you familiar with aflatoxin in peanuts?" This captures whether the farmer has any knowledge of aflatoxins in peanuts, and it is a general question that was asked to get an honest response from farmers.
} 
drying practice, because it separates the peanuts from the soil, which is a continuous potential source of aflatoxin producing mold, reduces drying time, and allows for more comfortable collection or covering in case of rain or during the evening due to security. ${ }^{5}$ Results on the length of the drying period are mixed with 35 percent of the households drying peanuts for 4-5 days, the minimum length of time estimated to achieve optimal moisture content $(<10$ percent) to inhibit continued mold growth and aflatoxin production. Results also indicate that 95 percent of the households sort peanuts to some degree before storage, another improved practice for aflatoxin control. In addition to asking farmers whether they sort or not since this is a common practice, we attempted to evaluate farmer's level of sorting by asking a follow-up, open-ended question to identify which types of peanuts should be removed and considered this answer as a proxy of sorting intensity. Farmers mentioned that they sort out moldy, immature, and broken peanuts. An additional dummy variable is created, which is equal to one if the farmer mentioned that they sort all types of highrisk peanuts (moldy, immature, and broken peanuts) [39]. Results show that 27 percent of farmers independently mentioned sorting all types of high-risk peanuts. Concerns have been raised that increased sorting may lead to increasing concentrations of aflatoxin in peanuts that may still be consumed by the poor or fed to livestock, so additional questions were asked related to what was done with the sorted peanuts. Most respondents replied that they threw them away, and 7 percent of the households use bad peanuts as fuel for cooking fires. Finally, our data suggest that storage takes place mainly at home (79 percent of households), with the remaining 21 percent at a depot.

\section{Empirical approach}

Two types of models are used in this paper. The first is a standard regression model of the form:

$$
Y_{i}=\alpha+\beta P_{i}+\gamma X_{i}+\varepsilon_{i},
$$

where $Y_{i}$ is the dependent variable (which in our case is the logarithm of yield), $P_{i}$ is a vector of control variables which describe production characteristics (including the type of peanut variety, whether the farmer uses irrigation and fertilizer, who makes decisions concerning production, etc.). $X_{i}$ is a vector of variables that include household demographics, and $\varepsilon_{i}$ is the error term. Many studies on agricultural productivity in developing countries (e.g.,

\footnotetext{
${ }^{5}$ These are subsistence households, and they are not aware of the potential adverse health effects from not appropriately drying peanuts and may not realize that a tarp is better than just laying them on the ground.
}

$[9,42])$ highlight the importance of credit availability and remittances on agricultural productivity and adoption of new technologies. We include remittances in our model, since there are limited formal credit markets reported for peanuts in rural Haiti. For example, Ngyen et. al. [26] find that rural households who receive remittances from migrants increase their land productivity. However, remittances come from migration which reduces the labor needed for agricultural activities in rural areas and they also contribute to household income which may affect investment in agriculture and productivity making remittances and yields endogenously determined [ 7 , 30]. We include the ownership of cattle, pigs, goats, or a horse as a proxy for wealth. Other variables included in the regression analysis are fertilizer use, owning a horse, ${ }^{6}$ slope of the field, and the variety of peanuts planted, which are standard production variables included in such studies. Household characteristics include whether the household is headed by a male or a female which may uncover important productivity differences [28, 34, 36], the level of education, which is also found to affect productivity in studies $[1,2]$, the number of adults in the household, which is a proxy for labor availability, whether the decisions are made jointly or by the female, as opposed to the male, and farming experience. Multicollinearity among explanatory variables may be a problem in our case. A variance inflation factor test for multicollinearity was applied, and the value was around 5 , which is well below the threshold value of 10 , suggesting that multicollinearity is not an issue in our specifications.

The second type of model used is a probit model where the outcome is a dummy variable (which in our case is equal to one, if (1) the households dry their peanuts on a tarp, if (2) the household has any knowledge on aflatoxins ${ }^{7}$ and if (3) the household sorts all types of bad peanuts (i.e., the highest level of sorting intensity), and it is equal to zero otherwise). The model is specified as follows:

$$
Y i=\beta X i+u_{i},
$$

where $Y_{i}$ represents a binary outcome variable, $\beta$ is a vector of parameters to be estimated, $X_{i}$ is a vector of explanatory variables and $u_{i}$ is the error term. Assuming that $u_{i}$ is normally distributed, a probit approach can be used to model the probability of adoption:

\footnotetext{
${ }^{6}$ Owning a horse can be both a wealth indicator and a productive asset since tractor use is very limited in Haiti, and some farm work is done with horses.

7 Since aflatoxin prevalence affects the price of peanuts and their safety we are trying to uncover channels that are associated with a higher probability of knowledge on aflatoxin such as education, working with an organization, household size, consumption, the structure of decision making in the household, etc.
} 
Table 3 The effects of household characteristics, household assets and production practices on peanut yields (dependent variable is log of peanut yield)

\begin{tabular}{lcc}
\hline Log of yield & Log of yield & \\
\cline { 2 - 3 } & Coef. & Std. Err. \\
\hline North & -0.27 & 0.49 \\
Female household head & $-0.22^{* *}$ & 0.09 \\
Wife makes decisions & 0.04 & 0.12 \\
Joint decisions & $0.15^{*}$ & 0.09 \\
Farming experience (years) & -0.01 & 0.00 \\
Uses irrigation & 0.04 & 0.14 \\
Remittances from abroad & 0.13 & 0.10 \\
Works with an organization & 0.05 & 0.10 \\
Runner variety & 0.34 & 0.47 \\
Peanut consumption & 0.01 & 0.01 \\
Primary education & 0.06 & 0.09 \\
Secondary education & 0.10 & 0.11 \\
College education & 0.14 & 0.21 \\
Other education & 0.08 & 0.30 \\
Pig (yes or no) & 0.06 & 0.07 \\
Cattle (yes or no) & 0.11 & 0.08 \\
Goats (yes or no) & -0.04 & 0.09 \\
Number of adults & -0.11 & 0.08 \\
Other jobs & $0.23^{* *}$ & 0.11 \\
Horse (yes or no) & -0.02 & 0.08 \\
Uses fertilizer & -0.14 & 0.19 \\
More than 1/2 of land in slope & $-0.27^{* *}$ & 0.13 \\
Constant & 5.18 & 0.21 \\
$R^{2}$ & 0.11 & \\
Adjusted R & 0.05 & \\
F & 333 & \\
N & & \\
\hline
\end{tabular}

***, ${ }^{* *},{ }^{*}$, mean significant at the 1 percent, 5 percent and 10 percent level, respectively

$$
\operatorname{Prob}(Y i)=\phi\left(\beta X i / \sigma_{u}\right)
$$

where $\phi$ (.) is the standard normal distribution function. The model will estimate the effect of $X_{\mathrm{i}}$ on the probability of the outcome variable being equal to 1 and is run three separate times, once for each dependent variable. Control variables in the probit model are similar to the ones used in Eq. (1). There is also concern for potential endogeneity between remittances and the use of tarp. ${ }^{8}$

\footnotetext{
${ }^{8}$ Following Bierkamp et al. [7] we use the highest level of education as an instrument for remittances and fail to reject the null hypothesis that the variables are exogenous for Eq. (1) as well as the probit model on tarp use.
}

\section{Results}

We present three sets of estimates. The first set of estimates relies on Eq. (1) and examines the determinants of yield (the dependent variable is the logarithm of yield) (Table 3). The second set of results uses probit models to examine factors that affect the probability of having any knowledge of aflatoxin and the probability of the use of tarp for drying (Table 4). Finally, Table 5 illustrates the results of the probit model with respect to sorting (Eq. 3).

\section{Peanut productivity}

Results in Table 3 illustrate the factors that influence peanut yield, where the dependent variable is the log of peanut yield. Results suggest that female-headed households have 22 percent lower yields compared to male-headed households. ${ }^{9}$ The difference in yields between the Northeast and the Central Plateau, as well as the yields of Runner and Valencia varieties, are not statistically significant ( $p$-value $=0.58)$. Runner varieties are more popular in the Northeast, while Valencia varieties are more popular in the Central Plateau. Results from the full sample suggest that when the decisions are made jointly, the yields are about 15 percent higher $(p$-value $=0.09)$ compared to those in households where the husband makes the decisions. Contrary to what one would expect, fertilizer use is (weakly) negatively correlated with yields and is not significant $(p$-value $=0.44)$. The result on the effect of fertilizer use on peanut yields in Haiti is similar to the one from Baffoe-Bonnie and Kostandini [3], who also found a negative effect. Farmers who also have other jobs besides agriculture appear to gain about 23 percent higher yields ( $p$-value $=0.04)$, suggesting that they may use some of the extra income to use more inputs in the production, such as hired labor for weeding. Finally, as expected, farmers that have more than half of their production on sloping land experience peanut yields, which are 27 percent lower than farmers that do not have more than half of their production area on sloping land, and this finding is consistent across all specifications.

\section{Aflatoxin knowledge and tarp use}

The next part of the analysis focuses on aflatoxin knowledge and the use of a tarp for drying. Results for this part are reported in Table 4, where the dependent variable is a dummy variable indicating whether the household has knowledge about aflatoxin (columns two and three) and whether the household uses a tarp for drying peanuts (last two columns). With respect to aflatoxin knowledge, results suggest that households in the Northeast

\footnotetext{
${ }^{9}$ We also included other variables and additional restrictions on the data sample in additional specifications, and the main results hold.
} 
Table 4 Probit model on aflatoxin knowledge and the use of tarp for drying

\begin{tabular}{|c|c|c|c|c|}
\hline & \multicolumn{2}{|l|}{ Aflatoxin knowledge } & \multicolumn{2}{|l|}{ Use of tarp } \\
\hline & Coef. & Std. Err. & Coef. & Std. Err. \\
\hline Aflatoxin knowledge & & & -0.50 & 0.34 \\
\hline Female household head & 0.25 & 0.23 & 0.14 & 0.27 \\
\hline Northeast & $1.93^{* * *}$ & 0.25 & $-3.85^{* * *}$ & 0.58 \\
\hline Wife makes decisions & $-0.96^{* *}$ & 0.43 & 0.48 & 0.35 \\
\hline Peanut production (thousand kg) & $0.42^{* *}$ & 0.03 & $0.76^{*}$ & 0.598 \\
\hline Saved seed from last season & 0.34 & 0.23 & $-0.88^{* *}$ & 0.35 \\
\hline Sorts all bad peanuts & 0.19 & 0.24 & $1.49^{* * *}$ & 0.32 \\
\hline Joint decisions & -0.26 & 0.24 & $0.44^{*}$ & 0.26 \\
\hline Farming experience (years) & $0.02^{*}$ & 0.01 & 0.002 & 0.01 \\
\hline Remittances from abroad & $0.55^{* *}$ & 0.26 & $0.86^{* *}$ & 0.36 \\
\hline Works with an organization & $1.21^{* * *}$ & 0.19 & 0.25 & 0.30 \\
\hline Peanut consumption (kg/year) & $0.04^{* *}$ & 0.02 & $-0.05^{* *}$ & 0.02 \\
\hline Primary education & -0.06 & 0.22 & -0.001 & 0.28 \\
\hline Secondary education & 0.15 & 0.28 & -0.23 & 0.31 \\
\hline College education & 0.50 & 0.59 & 0.85 & 0.76 \\
\hline Other education & 0.98 & 0.72 & 0.09 & 0.92 \\
\hline Number of adults & 0.18 & 0.22 & -0.07 & 0.26 \\
\hline Number of children & -0.03 & 0.05 & 0.04 & 0.06 \\
\hline Other jobs & 0.31 & 0.28 & $0.70^{* *}$ & 0.31 \\
\hline Constant & -2.87 & 0.56 & -0.31 & 0.60 \\
\hline \multirow[t]{4}{*}{ N } & 378 & & 378 & \\
\hline & $\operatorname{LRChi}^{2}(18)=236.4$ & & $\operatorname{LRChi}^{2}(19)=315.7$ & \\
\hline & Prob $>$ Chi $^{2}=0.0000$ & & Prob $>\mathrm{Chi}^{2}=0.0000$ & \\
\hline & Pseudo- $R^{2}=0.4858$ & & Pseudo- $R^{2}=0.6047$ & \\
\hline
\end{tabular}

***,,$* * *$, mean significant at the 1 percent, 5 percent and 10 percent level, respectively

and those that have interacted with an organization are a lot more likely to have heard about aflatoxin compared to households in the Central Plateau. Meds \& Food for Kids and other organizations such as Food and Agriculture Organization (FAO), who are focused on peanut production and peanut-related products, are present in the Northeast, and farmers may be familiar with these groups and their training materials or product specification requirements for sales. Households that consume more peanuts throughout the year, those that receive remittances from abroad, and those with more years of cultivating peanuts experience also have a higher likelihood of aflatoxin knowledge. Finally, households, where the decisions about peanut production are made by the wife are less likely to know about aflatoxin, which may be explained by how men and women may have different access to peanut production information related to local development initiatives.

The results on the tarp use for drying peanuts suggest that farmers in the Northeast are less likely to use a tarp. This is a bit surprising as they are more likely to be aware of aflatoxin than the households in the Central Plateau, though overall levels of awareness are low (31 percent), and farmers may not make the connection between aflatoxin contamination and tarp usage. Households are also more likely to use a tarp for drying peanuts when both the husband and the wife make decisions together, and, in our sample, about 59 percent of the households stated that they make decisions together. In addition, households with remittances from abroad and those that also have some type of off-farm income (other jobs) are more likely to use a tarp compared to those with no remittances or off-farm income, suggesting that wealthier households are more likely to be able to afford a tarp and to use it for drying peanuts. Given that tarp use was found to reduce aflatoxin levels by up to 30 percent in Ghana [25], identifying methods that will increase tarp use, such as microcredit or subsidies for tarp purchases by targeted farmers will be important in lowering aflatoxin prevalence. Tarp use appears to be negatively correlated with peanut consumption. More specifically, the marginal effects coefficient on peanut consumption suggests that a $1 \mathrm{~kg}$ increase on peanut consumption per year is associated with a 2 percent decrease in the likelihood of using 
Table 5 Probit model on the use of sorting all bad peanuts (dependent variable is equal to one if the household sorts molded, broken and immature peanuts and zero if it sorts less than that)

\begin{tabular}{|c|c|c|c|c|}
\hline & \multicolumn{2}{|c|}{ Sorts all bad peanuts } & \multicolumn{2}{|c|}{ Marginal effects } \\
\hline & Coef. & Std. Err. & Coef. & Std. Err. \\
\hline Aflatoxin knowledge & 0.21 & 0.27 & 0.04 & 0.05 \\
\hline Female household head & 0.26 & 0.24 & 0.05 & 0.05 \\
\hline Northeast & 0.14 & 0.39 & 0.02 & 0.07 \\
\hline Wife makes decisions & 0.18 & 0.40 & 0.03 & 0.08 \\
\hline Uses tarp to dry peanuts & $1.62^{* * *}$ & 0.34 & $0.32^{* * *}$ & 0.07 \\
\hline Peanut production (kgs) & -0.17 & 0.424 & -0.1 & 0.074 \\
\hline Saved seed from last season & $1.87^{* * *}$ & 0.0001 & $0.36^{* * *}$ & 0.05 \\
\hline Joint decisions & $0.55^{* *}$ & 0.27 & $0.09 * *$ & 0.04 \\
\hline Farming experience (years) & 0.004 & 0.01 & 0.0008 & 0.002 \\
\hline Remittances from abroad & $0.47^{*}$ & 0.27 & 0.1 & 0.07 \\
\hline Works with an organization & -0.17 & 0.23 & -0.02 & 0.04 \\
\hline Peanut consumption (kg/year) & -0.02 & 0.02 & -0.004 & 0.004 \\
\hline Primary education & 0.05 & 0.26 & 0.009 & 0.05 \\
\hline Secondary education & 0.25 & 0.31 & 0.05 & 0.06 \\
\hline College education & 0.28 & 0.58 & 0.06 & 0.14 \\
\hline Other education & 0.44 & 0.93 & 0.10 & 0.26 \\
\hline Number of adults & -0.33 & 0.24 & -0.06 & 0.04 \\
\hline Number of children & 0.002 & 0.05 & 0.0005 & 0.009 \\
\hline Other jobs & -0.20 & 0.29 & -0.04 & 0.06 \\
\hline Constant & $-2.61^{* * *}$ & 0.69 & & \\
\hline \multirow[t]{4}{*}{ N } & 378 & & 378 & \\
\hline & LR Chi2(19)= 164.2 & & & \\
\hline & Prob $>$ Chi $2=0.0000$ & & & \\
\hline & Pseudo-R2 $=0.4181$ & & & \\
\hline
\end{tabular}

$* * * * * *$, mean significant at the 1 percent, 5 percent and 10 percent level, respectively

a tarp for drying peanuts. ${ }^{10}$ Thus, as peanut consumption increases, the likelihood of using tarp decreases. This suggests that farmers who use tarps may have a stronger market orientation. Finally, households that report saving seed from the previous year are found to be less likely to use a tarp.

Results from the probit model, where the dependent variable is a dummy variable equal to one if the farmer was ranked as our highest level of sorting intensity (mentioned using all the types of targeted high-risk peanuts-immature, broken and moldy) and zero otherwise, are presented in Table 5. As mentioned, the dependent variable here is a proxy for the intensity and awareness that respondents put into sorting out the high-risk peanuts. Even though almost all (95 percent) of respondents stated that they sort their peanuts, only 27 percent of the respondents effectively listed the targets of the sorting (immature, broken, and moldy). There is a strong

\footnotetext{
${ }^{10}$ Marginal effects are available upon request.
}

disincentive for farmers to heavily sort their peanuts in Haiti since the product is measured volumetrically using a standard-sized \#10 can (marmit), and there are no grade standards and a limited level of quality valuation. Therefore, this study was also interested in ascertaining some measure of the quality of sorting. As mentioned above, while it is impossible to measure the effectiveness of sorting in a questionnaire format, using an openended question format, we created a metric using the depth of response to the question relating to which types of high-risk peanuts should be removed. So, we create a dummy variable equal to one if the household sort immature, broken, and moldy peanuts and equal to zero if they sort only one or two of the three. Thus, one means that the quality of sorting is of higher intensity. The coefficients of the probit model, where the dependent variable is whether the household sorts all three types of bad peanuts, are reported in column two, and marginal effects are presented in column three. There are three main findings from these results. First, households that use a tarp for drying peanuts have a 32 percent higher chance of more 
stringently sorting compared to households that did not rank on the sorting intensity metric, suggesting that tarp use is positively associated with increased efforts in sorting. Second, results indicate that households that saved seeds from last season have a 36 percent higher probability of more stringently sorting their peanuts compared to households that did not save seed from last season. This suggests that households that use part of their peanut production for seed are more careful in sorting their peanuts compared to those that do not. Third, findings indicate that households, where decisions are made by both the husband are 9 percent more likely to more stringently sort their peanuts compared to households where one of them makes the decisions related to peanut production and post-harvest practices independently.

\section{Discussion and conclusions}

This study provides evidence on peanut yields and peanut production practices in Haiti using a recent household survey. The study finds that there is a large yield gap between reported and realistic potential yield, suggesting that using improved production practices should generate higher yields, resulting in increasing food security and the welfare of smallholder farmers in Haiti. For example, Fulmer et al. [14] showed using fungicides, and improved management practices can potentially increase yields by as much as ten times, even with traditional varieties [15]. A very low level of input use is found, suggesting that programs and policies that will increase the availability of appropriate inputs, such as targeted fungicide applications, may help peanut farmers significantly increase yields.

Other issues examined include the social and environmental factors associated with higher yields and factors that affect the use of a tarp for drying peanuts among farming households in the Northeast and the Central Plateau in Haiti. The study provides evidence that female-headed households are less productive in terms of yield than male-headed households. In addition, our findings suggest that remittances from abroad are positively correlated with yield. These findings are likely related in that wealthier households with available cash are more likely to use more inputs, such as additional seed or labor. Conversely, the data show that farming of peanuts on steep land, which is common among Haitian farmers, puts a penalty of as much as 24 percent or more on peanut yields. Likewise, during the formative research period, the concern for the impact of peanut farming on exacerbating soil erosion was raised by MARDNR and other NGOs relative to their interest in promoting peanut in the country. This finding related to the yield penalty suggests that farmers in Haiti could greatly benefit from methods that improve productivity for sustainably farming on sloping land or should consider alternative crops to peanuts. Studies (e.g., [8] have found increased productivity when using methods that promote soil conservation on slopes, so focusing such methods in Haiti and their effect on peanut productivity could be an area for future research.

Results suggest that households with more access to capital, as measured by off-farm income and receiving remittances, are associated with an increase in the likelihood of tarp use, which may reduce levels of aflatoxin contamination [19]. In addition, aflatoxin awareness increases among households that are situated in the Northeast where there is more presence of organizations that work on increasing peanut productivity and want safer and higher quality peanuts for their peanut-related products (e.g., Meds \& Food for Kids). Thus, programs that improve aflatoxin awareness and programs that lower liquidity constraints for small peanut farmers may have positive effects on peanut productivity, aflatoxin awareness, and increase tarp use among Haitian smallholder farmers. Efforts to intensify sorting and educate farmers on the benefits of sorting may also be very beneficial not only for farmers but also for the consumers and aggregators. In addition, encouraging joint decisions when it comes to peanut production and post-harvest practices, promoting tarp use, and saving more seed may also increase the level of sorting efforts, which will lower aflatoxin prevalence and increase food security.

Overall, our findings suggest that peanut farmers in Haiti and other developing countries where yields are still comparatively low could benefit from programs that target improved access to production resources targeting female producers, increased access to inputs with proven return on investment, as well as programs that increase awareness on post-harvest practices that affect peanut quality and increase food security. This study focuses on 2014 data, and this may not be a typical year for agricultural productivity in Haiti, as it experienced some drought in that year [10]. Future studies that include additional information on household decision-making and panel data may provide fruitful insights on peanut production in Haiti.

\section{Acknowledgements}

This study was made possible by the generous support of the American people through the United States Agency for International Development (USAID) through Award No. AID-ECG-A-00-07-0001 to the University of Georgia as management entity for U.S. Feed the Future Innovation Lab on Peanut Productivity and Mycotoxin Control (2012-2017). The contents are the responsibility of the authors and do not necessarily reflect the views of USAID or the United States Government.

\section{Authors' contributions}

GKo: was involved in all aspects of the paper. JRh: data collection and interpretation, results interpretation, paper writing. GMc, JRo, ECa and GPr: data collection and interpretation, paper writing. ETa: was invloved in all aspects of the paper. 


\section{Funding}

Funding for this research was provided by the Peanut Innovation Lab which is one of the research labs funded by the United States Agency for International Development.

\section{Availability of data and materials}

Not applicable.

\section{Declarations}

\section{Ethics approval and consent to participate}

Not applicable.

\section{Consent for publication}

Not applicable.

\section{Competing interests}

The authors declare that they have no competing interests.

\section{Author details}

'Department of Agricultural and Applied Economics, University of Georgia, 206 Stuckey Building, Griffin, GA 30223, USA. ${ }^{2}$ University of Georgia, 224 Hoke Smith Building, 1225 S. Lumpkin Street, Athens, GA 30602-4356, USA. ${ }^{3}$ University of Florida, PO Box 110500, Gainesville, FL 32611-0500, USA. Department of Economics, Radford University, P.O. Box 6952, Radford, VA 24142, USA.

${ }^{5}$ Acceso Haiti, Port-au-Prince, Haiti. ${ }^{6}$ Quisqueya University, Port au Prince, Haiti.

Received: 13 October 2020 Accepted: 27 May 2021

Published online: 25 October 2021

\section{References}

1. Alene AD, Manyong VM. The effects of education on agricultural productivity under traditional and improved technology in northern Nigeria: an endogenous switching regression analysis. Empirical Econ. 2007;32(1):141-59.

2. Appleton S, Balihuta A. Education and agricultural productivity: evidence from Uganda. University of Oxford, Centre for the Study of African Economies;1996

3. Baffoe-Bonnie A, Kostandini G. Production efficiency of peanut farmers: The case of Haitian Peanut Farmers. Working paper. University of Georgia; 2018

4. Barton-Dock M, Singh RJ. Haiti: toward a new narrative-systematic Country Diagnostic. Washington DC: The World Bank; 2015.

5. Barrett CB. Overcoming global food security challenges through science and solidarity. Am J Agr Econ. 2021;103(2):422-47.

6. Beegle K, Carletto C, Himelein K. Reliability of recall in agricultural data. The World Bank; 2011.

7. Bierkamp S, Nguyen TT, Grote U. Environmental income and remittances: Evidence from rural central highlands of Vietnam. Ecol Econ. 2021;179:106830.

8. Byiringiro F, Reardon T. Farm productivity in Rwanda: effects of farm size, erosion, and soil conservation investments. Agric Econ. 1996;15(2):127-36.

9. Diagne A, Zeller M, Sharma M. Empirical measurements of households' access to credit and credit constraints in developing countries: methodological issues and evidence. Discussion paper, food consumption and nutrition division. Washington, DC: International Food policy Research Institute; 2000.

10. Food and Agriculture Organization (FAO). El NINO response: Haiti. 2016. http://www.fao.org/fileadmin/user_upload/emergencies/docs/1_web_ FAO\%20El\%20Nino\%20Response\%20Plan_final.pdf.

11. FAO. The state of food and agriculture: Women in agriculture-closing the gender gap for development. Rome, Italy: FAO; 2011. http://www.fao. org/docrep/013/i2050e/i2050e.pdf.

12. FAO. How to feed the world in 2050. High-level experts forum. Rome: Food and Agriculture Organization of the United Nations; 2009.
13. Filbert ME, Brown DL. Aflatoxin contamination in Haitian and Kenyan peanut butter and two solutions for reducing such contamination. J Hunger Environ Nutr. 2012;7(2-3):321-32.

14. Fulmer A, MacDonald G, Brenneman T, Kemerait R, Rhoads J, Caroll A, Macajoux R, Faroutine R, Sheard W, Laforest D, Dorzin P. Haiti Peanut Research Report. Athens, GA; 2018. https://secure.caes.uga.edu/exten sion/publications/files/pdf/B1499_1.PDF .

15. Fulmer AM, Brenneman TB, Kemerait RC, Macajoux R, Carroll DA, Faroutine G, Sheard W, Dorzan P, Rhoads JA, MacDonald GE. Evaluation of improved valencia peanut varieties for production in Haiti. Peanut Sci. 2020;47(1):1-8.

16. Food and Agriculture Organization of the United Nations, FAOSTAT database (FAOSTAT, 2016). 2016. http://faostat.fao.org/.

17. Gong YY, Watson S, Routledge MN. Aflatoxin exposure and associated human health effects, a review of epidemiological studies. Food Saf. 2016:4(1):14-27.

18. Hailu BK, Abrha BK, Weldegiorgis KA. Adoption and impact of agricultural technologies on farm income: evidence from Southern Tigray, Northern Ethiopia. Int J Food Agric Econ. 2014;2(1128-2016-92058):91-106.

19. Magnan N, Hoffmann V, Opoku N, Garrido GG, Kanyam DA. Information, technology, and market rewards: incentivizing aflatoxin control in Ghana. J Dev Econ. 2021;151:102620.

20. Ibrahim M, Florkowski W, Kolavalli S. 2012. The determinants of farmer adoption of improved peanut varieties and their impact on farm income: evidence from Northern Ghana. Selected paper prepared for presentation at the Agricultural and Applied Economics Association Annual Meeting, Seattle, WA, August 12-14, 2012.

21. Jolly CM, Prophete E. Peanut production: An environmental dilemma for Haitian rural communities, pp. 195-207. In Pemberton CA editor. Rural Development Challenges in the Next Century. Proc. VI Latin America and Caribbean Agricultural Economic Conference, Department of Agricultural, Economics and Extension, The University of West Indies, St.Augustine, Trinidad; 2001.

22. Kassie M, Shiferaw B, Muricho G. Agricultural technology, crop income, and poverty alleviation in Uganda. World Dev. 2011;39(10):1784-95.

23. Launio CC, Luis JS, Angeles YB. Factors influencing adoption of selected peanut protection and production technologies in Northern Luzon, Philippines. Technol Soc. 2018;1(55):56-62.

24. Lybbert T, Tescar RB. Putting the 'system of rice intensification' to the test among Haitian farmers. BASIS Assets and Market Innvoation Lab. Policy Brief. 2014. Available at: https://basis.ucdavis.edu/sites/g/files/ dgvnsk466/files/2017-01/Lybbert-Travis1_0.pdf.

25. Mintz SW. Standards of value and units of measure in the Fonddes-Nègres market place, Haiti. J R Anthropol Inst Great Br Irel. 1961;91(1):23-38.

26. Nguyen DL, Grote U, Nguyen TT. Migration, crop production and non-farm labor diversification in rural Vietnam. Econ Anal Policy. 2019;1(63):175-87.

27. Padgett A, Warnecke T. Diamonds in the rubble: the women of Haiti: Institutions, gender equity and human development in Haiti. J Econ Issues. 2011;45(3):527-58.

28. Peterman A, Quisumbing A, Behrman J, Nkonya E. Understanding the complexities surrounding gender differences in agricultural productivity in Nigeria and Uganda. J Dev Stud. 2011;47(10):1482-509.

29. PMIL (Peanut and Mycotoxin Innovation Lab). 2017. http://www.caes. uga.edu/global/feed-the-future-innovation-labs/peanut-mycotoxininnovation-lab.html.

30. Rozelle S, Taylor JE, DeBrauw A. Migration, remittances, and agricultural productivity in China. Am Econ Rev. 1999;89(2):287-91.

31. Simtowe F, Kassie M, Asfaw S, Shiferaw BA, Monyo E, Siambi M. Welfare effects of agricultural technology adoption: the case of improved groundnut varieties in rural Malawi; Selected Paper prepared for presentation at the International Association of Agricultural Economists (IAAE) Triennial Conference, Foz do Iguaçu, Brazil, 18-24 August, 2012.

32. Schwartzbord JR, Brown DL. Aflatoxin contamination in Haitian peanut products and maize and the safety of oil processed from contaminated peanuts. Food Control. 2015;1(56):114-8.

33. Schwartzbord J, Brown DL, Pape JW, Verdier RI, Filbert M, Wang JS. Aflatoxin-lysine adducts in haitian patients ingesting peanut and maize products. J Hunger Environ Nutr. 2014;9(2):244-55. 
34. Tanellari E, Kostandini G, Bonabana-Wabbi J, Murray A. Gender impacts on adoption of new technologies: the case of improved groundnut varieties in Uganda. Afr J Agric Resour Econ. 2014;9(311):300-8.

35. Tefera T, Tefera T, Kanampiu F, De Groote H, Hellin J, Mugo S, Kimenju S, Beyene Y, Boddupalli PM, Shiferaw B, Banziger M. The metal silo: An effective grain storage technology for reducing post-harvest insect and pathogen losses in maize while improving smallholder farmers' food security in developing countries. Crop Prot. 2011;30(3):240-5.

36. Udry C, Hoddinott J, Alderman H, Haddad L. Gender differentials in farm productivity: implications for household efficiency and agricultural policy. Food Policy. 1995;20(5):407-23.

37. U.S. Department of State. Status of post-earthquake recovery and development efforts in Haiti. December 2016. https://www.state.gov/p/wha/ ci/ha/hsc/2016report/index.htm. Accessed 19 Dec 2017

38. Varga J, Frisvad J, Samson R. A reappraisal of fungi producing aflatoxins. World Mycotoxin J. 2009;2(3):263-77.
39. Whitaker TB, Hagler WM Jr, Giesbrecht FG. Performance of sampling plans to determine aflatoxin in farmers'stock peanut lots by measuring aflatoxin in high-risk-grade components. J AOAC Int. 1999;82(2):264-70.

40. The World Bank and ONPES. Investing in people to fight poverty in haiti, reflections for evidence based policy making. Washington, DC: The World Bank; 2014

41. The World Bank. The World Bank in Haiti. 2019. https://www.worldbank. org/en/country/haiti/overview. Accessed Nov 2019.

42. Wouterse F. Migration and technical efficiency in cereal production: Evidence from Burkina Faso. Agric Econ. 2010;41(5):385-95.

\section{Publisher's Note}

Springer Nature remains neutral with regard to jurisdictional claims in published maps and institutional affiliations.
Ready to submit your research? Choose BMC and benefit from:

- fast, convenient online submission

- thorough peer review by experienced researchers in your field

- rapid publication on acceptance

- support for research data, including large and complex data types

- gold Open Access which fosters wider collaboration and increased citations

- maximum visibility for your research: over $100 \mathrm{M}$ website views per year

At BMC, research is always in progress.

Learn more biomedcentral.com/submissions 